\title{
Myths and Misconceptions about the Psychology of Adolescence and Intimate Relationships
}

\author{
Adrian Furnham ${ }^{1 *}$, Simmy Grover ${ }^{2}$ \\ ${ }^{1}$ Department of Leadership and Organisational Behaviour, Norwegian Business School (BI), Nydalveien, Olso, Norway \\ ${ }^{2}$ Department of Experimental Psychology, University College London, London, UK \\ Email: *adrian@adrianfurnham.com
}

How to cite this paper: Furnham, A., \& Grover, S. (2019). Myths and Misconceptions about the Psychology of Adolescence and Intimate Relationships. Psychology, 10, 2166-2176.

https://doi.org/10.4236/psych.2019.1015137

Received: November 29, 2019

Accepted: December 24, 2019

Published: December 27, 2019

Copyright $\odot 2019$ by author(s) and Scientific Research Publishing Inc. This work is licensed under the Creative Commons Attribution International License (CC BY 4.0).

http://creativecommons.org/licenses/by/4.0/

\begin{abstract}
This study examined the prevalence of psychological myths in two areas of psychology: Adolescence and Relationships. All 517 participants completed two questionnaires in which they rated to what extent they thought various statements/facts about Adolescence and about Intimate Relationships were True or False. A large number of these myths were rated as True (Definitely or Partly). There were few significant demographic correlates of the total correct score (determined by rating the myth as False). Implications are discussed.
\end{abstract}

\section{Keywords}

Psychology, Education, Myths, Misconceptions, Psychological Knowledge

\section{Introduction}

There has been an academic interest in psychological myths and misconceptions for nearly a hundred years (Amsel, Baird, \& Ashley, 2011; Brown, 1983; Furnham, 1992, 1993; Gaze, 2014; Hughes, Lyddy, \& Lambe, 2013; Kowalski \& Taylor, 2009; Nixon, 1925; Lamal, 1979; McKeachie, 1960; Taylor \& Kowalski, 2004; Tupper \& Williams, 1986; Vaughan, 1977). Studies have assessed student's psychological knowledge with a view to evaluating the success of introductory courses (Arntzen, Lokke, Lokke, \& Eilertsen, 2010; Gardner \& Dalsing, 1986; Griggs \& Ransdell, 1987; Lamal, 1979; McKeachie, 1960; Standing \& Huber, 2003; Vaughan, 1977). Results have shown high levels of misconception (40\% $70 \%)$ prior to education, which are reduced, but only slightly, following education methods (LaCaille, 2015). Similarly, Hughes, Lyddy \& Kaplan (2015) found years of university education and psychology courses completed were related to 
fewer misconceptions about psychology.

This research area has been stimulated by Lilienfeld, Lynn, Ruscio, and Beyerstein (2010), 50 Great Myths of Popular Psychology which reviewed and dispelled 50 myths. Numerous studies have used the 50 and 250 myths to test various hypotheses in this area (Furnham \& Hughes, 2014; Furnham, 2018; Swami et al., 2015). Further other recent books have been published looking at specific myths (DeBruyckere, Kirschner, \& Hulshof, 2015).

The study has encouraged researchers to develop new scales such as Gardner and Brown (2013) who developed a new 55-item measure of psychological misconceptions. Overall scores on this test were significantly and negatively correlated with reported reading of news magazines. Bensley, Lilienfeld and Powell (2014) also developed a 40-item measure based on the same source. They showed believing in psychological misconceptions was predicted by measures of paranormal belief, faith in intuition, the ability to distinguish scientific fields and practices from pseudoscientific ones, and academic scores.

Lilienfeld et al. (2010) inspired various other more specialised books with a very similar title and format. This study is based on two of these books. The first was entitled Great Myths of Adolescence (Jewell et al., 2019) which lists (and explains) 50 myths categorised under four headings: Development of the Body, Brain and Mind; Development of the Self; The Social Environment; and Problems in Modern Society. The second was Great Myths of Intimate Relationships (Johnson, 2016) which lists 25 myths under six headings: Sex; Attraction and courtship; Online dating; Same sex relationships; Predicting success and failure in relationships; Differences, discord and dissolution. In this study we followed Funrham (2018) who used the myths set out in these two books using the methodology of Furnham and Hughes (2014) who asked participants to rate each myth as Definitely True, Probably True, Probably False, Definitely False or Don't Know. He hypothesised and demonstrated, based on previous results, that for over $50 \%$ of the myths in both categories participants would rate them as Definitely or Probably True. Overall it seemed that participants were better at identifying Brain Myths compared to Child Developmental myths. The results also showed that similar to the study of Furnham and Hughes (2014) that around 15\% - 20\% answered Don't Know to the questions. Both the correlational and regression results did indicate one individual difference marker of myth detection. Those who rated themselves higher on "having common sense" were better detectors of myths.

\section{Method}

\subsection{Participants}

A total of 517 participants completed the questionnaire: 259 were men and 258 were women. A power analysis suggested that this was sufficient to test our hypotheses. They ranged in age from 18 to 70 years with the mean age was 21.48 years and $S D=8.3$ years. All participants had at least a secondary school educa- 
tion and $37 \%$ were graduates. $46.4 \%$ of the sample had children. Additionally, they rated themselves on three scales: How religious are you? (Not all at 1 to Very 8$)$ and they scored $2.09(S D=2.75)$; How would you describe your political beliefs? (Very Left Wing 1 to Very Right Wing 8); they scored $5.38(S D=1.97)$; How Optimistic are you (Not at all 1 to Very 8$)$ they scored $5.68(S D=1.94)$.

\subsection{Measures}

The myths and misconceptions were derived from two books, as noted above. Response options were broken down into "Probably" and "Definitely" True or False allowing for greater information to be gleaned regarding the kinds of True and False responses. In addition, the "Don't Know" option improves upon some previous tests as participants could indicate a lack of knowledge, rather than guessing or leaving items unanswered (Arntzen et al., 2010).

\subsection{Procedure}

Departmental ethical approval, based on UCL guidelines was gained prior to data collection (CEHP/2017/514). Data was collected on Prolific and participants were compensated for their time. The questionnaire took an average of $40 \mathrm{mi}-$ nutes to complete.

\section{Results}

\subsection{Prevalence of Misconceptions}

All of the items presented were myths, thus for all items, the "correct" answer was False (Probably or Definitely). Participants' False responses were summed in order to create a myth recognition score for each of the two questionnaires.

Myths About Adolescence: Table 1 shows the results for the 50 developmental myths. In all 6 were identified by more than $50 \%$ of the participants as Definitely False: 3, 22, 23, 27, 45 and 49. When the Definitely and Probably False were combined 22 of the myths were correctly identified as false by over $50 \%$ of the sample.

On the other hand, there were no items where over $40 \%$ of the respondents said that the following items were Definitely True. However, there were 11 where more than 200 respondents (40\%) said they were Probably True. They were items 2, 5, 9, $10,12,15,26,28,29,38,41$. When the Definitely and Probably True were combined 11 of the myths were incorrectly identified by the sample.

On 18 items over 100 respondents (20\%) said that they Don't Know: The highest scores were for items 6, 8, 44, and 47.

Relationship Myths: Table 2 shows the results for the 25 relationship myths. In all 4 were identified by more than $50 \%$ of the participants as Definitely False. They were items 2, 4, 13 and 22. When the Definitely and Probably False were combined 12 of the myths were correctly identified as false by over $50 \%$ of the sample.

On the other hand there were 5 items where over $30 \%$ of the respondents 
Table 1. Item level analyses for Myths about Adolescence.

\begin{tabular}{|c|c|c|c|c|c|c|}
\hline & Statement & DT & PT & PF & $\mathrm{DF}$ & $\mathrm{DK}$ \\
\hline 1 & Adolescence ends at 18 years old & 62 & 142 & 145 & 138 & 30 \\
\hline 2 & $\begin{array}{l}\text { Girls are universally experiencing puberty } \\
\text { sooner in recent years }\end{array}$ & 137 & 258 & 44 & 10 & 68 \\
\hline 3 & The teen brain is fully developed at age 18 & 14 & 77 & 160 & 234 & 32 \\
\hline 4 & $\begin{array}{l}\text { Anorexia treatment usually requires teenagers } \\
\text { to be separated from their parents }\end{array}$ & 10 & 76 & 128 & 138 & 165 \\
\hline 5 & Technology has made teenagers better at multitasking & 55 & 206 & 145 & 55 & 56 \\
\hline 6 & Pubertal "early bloomers" fare better than "late bloomers" & 6 & 57 & 132 & 60 & 262 \\
\hline 7 & Teenagers can study better while listening to music & 37 & 198 & 138 & 50 & 94 \\
\hline 8 & On average 15 years olds gain 15 pounds in that year & 2 & 66 & 116 & 103 & 230 \\
\hline 9 & $\begin{array}{l}\text { Horses are helpful in the treatment of eating } \\
\text { disorders and autism spectrum }\end{array}$ & 74 & 208 & 38 & 27 & 170 \\
\hline 10 & The onset of puberty is very upsetting to most teenagers & 94 & 261 & 95 & 27 & 40 \\
\hline 11 & $\begin{array}{l}\text { Male teenagers are much less likely than females to } \\
\text { be preoccupied with their physical appearance }\end{array}$ & 44 & 173 & 179 & 80 & 41 \\
\hline 12 & $\begin{array}{l}\text { Most teenagers hardly ever engage in leisure reading } \\
\text { these days }\end{array}$ & 84 & 227 & 123 & 45 & 38 \\
\hline 13 & $\begin{array}{l}\text { Joining groups or societies has a negative effect on } \\
\text { students' academic success }\end{array}$ & 9 & 42 & 226 & 192 & 48 \\
\hline 14 & $\begin{array}{l}\text { Paying for practice classes is the best way to do well on } \\
\text { intelligence tests }\end{array}$ & 18 & 119 & 161 & 106 & 113 \\
\hline 15 & Significant mood disruptions in adolescence are inevitable & 120 & 257 & 76 & 17 & 47 \\
\hline 16 & $\begin{array}{l}\text { Teenagers should have a job in high school to build } \\
\text { character }\end{array}$ & 53 & 185 & 114 & 81 & 84 \\
\hline 17 & Risky behaviour in adolescence is inevitable & 47 & 196 & 144 & 74 & 56 \\
\hline 18 & $\begin{array}{l}\text { Taking care of an infant simulator doll increases } \\
\text { abstinence from sexual activity }\end{array}$ & 10 & 78 & 146 & 125 & 158 \\
\hline 19 & $\begin{array}{l}\text { Vocational tests are useless at predicting academic } \\
\text { success in college }\end{array}$ & 46 & 172 & 149 & 43 & 107 \\
\hline 20 & College students' lives are full of random "hook-ups" & 31 & 180 & 157 & 73 & 76 \\
\hline 21 & $\begin{array}{l}\text { Teaching teenagers about contraception makes them more } \\
\text { likely to engage in sexual activity }\end{array}$ & 15 & 91 & 195 & 166 & 50 \\
\hline 22 & $\begin{array}{l}\text { Abstinence only sex education programmes are effective at } \\
\text { keeping teenagers abstinent }\end{array}$ & 7 & 46 & 136 & 262 & 66 \\
\hline 23 & The HPV vaccine increases teenage sex & 5 & 32 & 111 & 227 & 142 \\
\hline 24 & The millennial generation is lazy & 54 & 136 & 119 & 173 & 35 \\
\hline 25 & $\begin{array}{l}\text { Highschool football players are more likely to become } \\
\text { seriously injured than cheerleaders }\end{array}$ & 78 & 159 & 141 & 44 & 95 \\
\hline 26 & $\begin{array}{l}\text { Offenders hide sexual interest when using the internet to } \\
\text { initiate sex offenses against teenagers }\end{array}$ & 86 & 207 & 49 & 21 & 154 \\
\hline 27 & $\begin{array}{l}\text { Conversion therapy effectively turns homosexual } \\
\text { teenagers straight }\end{array}$ & 4 & 23 & 61 & 359 & 70 \\
\hline
\end{tabular}




\section{Continued}

\begin{tabular}{|c|c|c|c|c|c|c|}
\hline 28 & $\begin{array}{l}\text { Unlike adults, teenagers underestimate the } \\
\text { consequences of risky behaviour }\end{array}$ & 137 & 273 & 64 & 23 & 20 \\
\hline 29 & $\begin{array}{l}\text { More quality time with teenagers can make up for less } \\
\text { quantity time }\end{array}$ & 60 & 245 & 84 & 19 & 109 \\
\hline 30 & $\begin{array}{l}\text { Successful transition from adolescence to adulthood is } \\
\text { achieved through detachment from parents }\end{array}$ & 34 & 155 & 154 & 114 & 60 \\
\hline 31 & Popular teenagers are usually mean/aggressive & 28 & 125 & 198 & 107 & 59 \\
\hline 32 & Peer pressure only causes teenagers to make bad decisions & 59 & 193 & 143 & 82 & 40 \\
\hline 33 & $\begin{array}{l}\text { Boys only use "sticks \& stones"/physical force while girls } \\
\text { use words instead }\end{array}$ & 29 & 103 & 149 & 212 & 24 \\
\hline 34 & $\begin{array}{l}\text { Most teenagers have a strained relationship with } \\
\text { their parents }\end{array}$ & 22 & 152 & 170 & 107 & 66 \\
\hline 35 & $\begin{array}{l}\text { Asking a student if they ever thought about suicide } \\
\text { "plants a seed" and makes them more likely to } \\
\text { actually attempt suicide }\end{array}$ & 10 & 71 & 158 & 207 & 71 \\
\hline 36 & Teenagers only listen to their peers & 17 & 94 & 191 & 178 & 37 \\
\hline 37 & When girls are sexually assaulted it is usually be a stranger & 12 & 64 & 181 & 208 & 52 \\
\hline 38 & Most college/university students graduate in 4 years & 34 & 233 & 100 & 39 & 111 \\
\hline 39 & College is the happiest time of one's life & 31 & 146 & 163 & 75 & 102 \\
\hline 40 & $\begin{array}{l}\text { Teenagers these days are worse behaved than those in } \\
\text { previous generations. }\end{array}$ & 84 & 112 & 155 & 102 & 64 \\
\hline 41 & School violence is on the rise & 117 & 218 & 75 & 31 & 76 \\
\hline 42 & Boot camps get teens "on the right track" & 17 & 108 & 151 & 96 & 145 \\
\hline 43 & Most teenagers party with drugs or alcohol on weekends & 77 & 185 & 145 & 65 & 45 \\
\hline 44 & DARE programmes prevent teenage drug use & 21 & 85 & 78 & 53 & 280 \\
\hline 45 & $\begin{array}{l}\text { Listening to heavy metal or rap music makes teenagers } \\
\text { more likely to defy authority }\end{array}$ & 11 & 80 & 135 & 251 & 40 \\
\hline 46 & Teenagers have the highest suicide rate & 44 & 149 & 126 & 60 & 138 \\
\hline 47 & $\begin{array}{l}\text { Goggles mimicking drunkenness helps prevent } \\
\text { impaired driving }\end{array}$ & 10 & 117 & 102 & 68 & 220 \\
\hline 48 & Teenagers can be "scared straight" & 21 & 123 & 108 & 139 & 126 \\
\hline 49 & Sexting is only a teenage problem & 6 & 19 & 120 & 344 & 28 \\
\hline 50 & $\begin{array}{l}\text { Traditional high school driver education courses have } \\
\text { a strong record of making teenagers safe drivers }\end{array}$ & 19 & 164 & 84 & 28 & 222 \\
\hline
\end{tabular}

Table 2. Item level analyses for Myths about Relationships.

\begin{tabular}{|c|c|c|c|c|c|c|}
\hline & Statement & DT & PT & $\mathrm{PF}$ & $\mathrm{DF}$ & DK \\
\hline 1 & Men have a stronger libido (sex drive) than women. & 92 & 198 & 115 & 75 & 37 \\
\hline 2 & $\begin{array}{l}\text { Hooking up in college (having sex at university) } \\
\text { is bad for women. }\end{array}$ & 18 & 49 & 178 & 234 & 38 \\
\hline 3 & $\begin{array}{l}\text { All marriages have been consummated } \\
\text { (partners have had sexual intercourse). }\end{array}$ & 57 & 126 & 143 & 139 & 52 \\
\hline
\end{tabular}




\section{Continued}

\begin{tabular}{|c|c|c|c|c|c|c|}
\hline 4 & All marriages are (and remain) sexually active. & 11 & 93 & 173 & 213 & 27 \\
\hline 5 & $\begin{array}{l}\text { Being smooth (acting sophisticated) is the best way } \\
\text { to pick someone up (start a relationship). }\end{array}$ & 22 & 176 & 155 & 98 & 66 \\
\hline 6 & $\begin{array}{l}\text { Opposites attract (people with opposite personality and } \\
\text { values are attracted to each other). }\end{array}$ & 27 & 183 & 176 & 76 & 55 \\
\hline 7 & People know what they want in a partner. & 41 & 183 & 176 & 87 & 30 \\
\hline 8 & $\begin{array}{l}\text { Having access to innumerable online of potential } \\
\text { partners increases the likelihood of finding } \\
\text { Mr or Ms Right. }\end{array}$ & 36 & 178 & 143 & 89 & 71 \\
\hline 9 & $\begin{array}{l}\text { Meeting potential partners electronically prior } \\
\text { to meeting them in person decreases the } \\
\text { chances of a successful relationship. }\end{array}$ & 12 & 110 & 211 & 98 & 86 \\
\hline 10 & $\begin{array}{l}\text { Couples who are "matched" by online dating services } \\
\text { are more likely to have satisfying relationships. }\end{array}$ & 14 & 85 & 201 & 83 & 134 \\
\hline 11 & $\begin{array}{l}\text { The gender to which people are attracted is stable } \\
\text { (over time). }\end{array}$ & 62 & 197 & 111 & 79 & 68 \\
\hline 12 & $\begin{array}{l}\text { There are no differences between same-sex } \\
\text { relationships and heterosexual relationships. }\end{array}$ & 134 & 140 & 109 & 92 & 42 \\
\hline 13 & $\begin{array}{l}\text { Children raised by other-sex couples are better off } \\
\text { than children raised by same-sex couples. }\end{array}$ & 42 & 68 & 96 & 223 & 88 \\
\hline 14 & $\begin{array}{l}\text { Living together before marriage is a good way to } \\
\text { determine whether you're with the right person. }\end{array}$ & 254 & 188 & 33 & 17 & 25 \\
\hline 15 & $\begin{array}{l}\text { Premarital counselling or relationship education } \\
\text { programs prevent discord and divorce. }\end{array}$ & 42 & 213 & 128 & 40 & 94 \\
\hline 16 & Good communication is the key to a happy relationship. & 390 & 99 & 15 & 9 & 4 \\
\hline 17 & $\begin{array}{l}\text { The key to a good relationship is knowing } \\
\text { how to solve your problems. }\end{array}$ & 247 & 210 & 29 & 10 & 21 \\
\hline 18 & Having children brings couples closer. & 55 & 171 & 127 & 83 & 81 \\
\hline 19 & Stress is bad for relationships. & 234 & 214 & 45 & 9 & 15 \\
\hline 20 & Supporting your partner will improve your relationship. & 344 & 141 & 18 & 8 & 6 \\
\hline 21 & $\begin{array}{l}\text { Men are from Mars, women are from Venus } \\
\text { (men and women are very different). }\end{array}$ & 114 & 155 & 121 & 87 & 40 \\
\hline 22 & Only men perpetrate violence in intimate relationships. & 4 & 31 & 81 & 380 & 21 \\
\hline 23 & Marital therapy doesn't work. & 10 & 52 & 217 & 106 & 132 \\
\hline 24 & $\begin{array}{l}\text { Psychological damage from (first) adolescent } \\
\text { relationships and break-ups is severe. }\end{array}$ & 62 & 220 & 103 & 17 & 115 \\
\hline 25 & Things will improve once you are divorced, & 15 & 111 & 117 & 50 & 224 \\
\hline
\end{tabular}

selected Definitely True: 14, 16, 17, 19, and 20. When the Definitely and Probably True were combined 9 of the myths were incorrectly identified by the sample.

On 4 items a fifth or more of the respondents said that they Don't Know: 10, $23,24,25$. 


\subsection{Correlates}

Two scores were then computed for each individual: the total scores in each questionnaire in which they had marked Definitely False. For the first questionnaire the score was $18.89(\mathrm{SD}=8.12)$ and the second $17.79(\mathrm{SD}=8.12)$. The correlation between the two was $\mathrm{r}=.79$ indicating considerable similarity in responses to the two questionnaires. These scores were then correlated with the various demographic and belief variables. There was no relationship between the total scores and age, gender, education, whether they had children and whether or not they had taken a course in psychology. Indeed, scores of those who had and had not some education in psychology were almost identical. Three variables were significant however for both total scores: they indicated that the more religious people rated themselves the higher their score: test $1, r=.24$, test $2, \mathrm{r}=.19$; the more politically conservative people rated themselves the higher their score (test $1, \mathrm{r}=.23$; test $2, \mathrm{r}=.18$ ) and the more they believed they had common sense the higher their score (test $1, \mathrm{r}=.22$; test $2, \mathrm{r}=.26$ ).

A number of regressions were then computed, with both test total scores as the criterion variable. In the first set age, gender, taken a psychology course and self-assessed common sense was entered as predictor variables. The regression was significant for both tests: test $1\left(\mathrm{~F}(4,219)=3.40, p<.01 ; \mathrm{Adj}^{2}=.04\right)$ and test $2\left(\mathrm{~F}(4,219)=4.57, p<.001\right.$; Adj $\left.\mathrm{R}^{2}=.06\right)$. In both cases only self-assessed common sense was significant Test 1 Beta- $.22, \mathrm{t}=3.37, p<.001$; Test 2 Beta .26 , $\mathrm{t}=4.05, p<.001)$. Those with higher self-assessed common sense were indeed more able to detect myths.

The two scores were then combined to produce a total score which served as a criterion variable. There were eight predictor variables: age, gender, education, taken a psychology course, self-assessed common sense, having children, religious beliefs and political beliefs. This was significant $(\mathrm{F}(8,211)=4.50, p<.001$, Adj $\mathrm{R}^{2}=.11$ ). Two variables were significant predictors: common sense (Beta $=.21, \mathrm{t}=3.13, p<.01)$ and religious beliefs (Beta $=.18, \mathrm{t}=2.47, p<.01)$. Those with higher self-rated common sense and greater religious beliefs were better able to detect these myths.

\section{Discussion}

The current results replicated findings of earlier studies on misconception prevalence (Arntzen et al., 2010; Furnham \& Hughes, 2014) showing that a large number of myths were widely believed. This paper adds to the growing literature that is dedicated to exploring various myths and misconceptions about particular psychological concepts. Indeed this study was provoked by a series of books all dedicated to this endeavor (Hupp \& Jewell, 2015; Jarrett, 2014; Jewell, Axelrod, Prinstein, \& Hupp, 2019; Johnson, 2016).

Overall it seemed that participants were better at identifying Myths about Relationships compared to Myths about Adolescence, though this may be for methodological reasons. Many researchers have categorized myths into various 
topics like learning and neuromyths (De Bruyckere et al., 2015) though the research tends to show that participants are not particularly better informed and better "myth-detectors" in some areas rather than others.

It should be pointed that when authors list myths of various kinds such as in the book series Great Myths in Psychology commissioned by Wiley they do not indicate the extent to which they believe (or have any data) on the extent to which people would endorse the myths. Nor do they write the statements in such a way as they may be easily understood without reading the subsequent text. In this sense the myths are not all equal which is the finding of this and other studies.

One interesting finding that was similar to the study of Furnham and Hughes (2014) was the fact that around 15\% - 20\% answered Don't Know to the questions. This number varied question by question but on average less than a fifth of respondents were prepared to admit that they did not know. We calculated the total scores for individuals on Don't Know but this was not systematically related to any of the demographic variables. It could be that people were too embarrassed to admit they did not know when indeed the evidence shows quite clearly that they did not.

This, like other studies in the area, failed to find any strong, clear or logical demographic correlates of myth accepting or rejecting. Age, gender and education were not related to total correct scores, nor education in psychology. Some, but not all, previous studies did establish a small but significant relationship between education in psychology and myth recognition (Furnham \& Hughes, 2014). This study found no such relationship; however this may be because of the lack of detail about that education. The question was simply "Did you ever take a course in psychology/psychiatry: Yes...No...”. As a result, we did not have details about the nature, depth and duration of the course, nor when and where it was undertaken.

Both the correlational and regression results did indicate one individual difference marker of myth detection. Those who rated themselves higher on "having common sense" were better detectors of myths. Descartes observed that common sense is the most widely distributed human characteristic because everybody believes they have a great deal of it which was reflected in the strong skew on this dimension. There was also some indication that religious and political beliefs were linked to myth detection though the correlations were low. The results were rather surprising showing that more religious and right-wing people tended to be better at myth detection.

Like all studies this had a number of limitations. First, the sample was heterogeneous but not fully representative in terms of age, religious views, marital status and educational attainment. It was also relatively small. We believe that a more representative sample would have more older people and those with less educational achievement; two factors that are associated with accepting more myths. It would however be most desirable to have collected data on whether the participants were parents of adolescence and how much contact they had with 
them. Similarly it would have been desirable to know more about the "relationship experiences" of the participants such as whether they had been divorced or indeed their parents had.

Next, in this study all the myths were indeed myths and therefore False. It may have been better to combine myths with "facts" to see if participants could distinguish the two. Third, not all of the myths were always clearly expressed or in the same style, no doubt because they were not written as questionnaire items.

Studies such as this provide useful historical data on psychological myth prevalent in society. They nearly always provide the "shocking truth" about the widespread acceptance of myths which nearly always concerns experts and educationists who call for attempt to dispel or debunk those myths.

The current study has shown that psychological myths and misconceptions (about adolescence and relationships) are abundant and persistent as well as potentially harmful and socially divisive. It is possible that myth-debunking campaigns designed around refutational methods akin to those used by Kowalski and Taylor (2009), Lilienfeld et al. (2010), and LaCaille (2015) have the potential to reduce levels of misconception. The current study can be used to identify myths and misconceptions in need of refutation.

\section{Conflicts of Interest}

The authors declare no conflicts of interest regarding the publication of this paper.

\section{References}

Amsel, E., Baird, T., \& Ashley, A. (2011). Misconceptions and Conceptual Change in Undergraduate Students Learning Psychology. Psychology, Learning and Teaching, 10, 3-10. https://doi.org/10.2304/plat.2011.10.1.3

Arntzen, E., Lokke, J., Lokke, G., \& Eilertsen, D.-E. (2010). On Misconceptions about Behavior Analysis among University Students and Teachers. Psychological Record, 60, 325-336. https://doi.org/10.1007/BF03395710

Bensley, D. A., Lilienfeld, S. O., \& Powell, L. A. (2014). A New Measure of Psychological Misconceptions: Relations with Academic Background, Critical Thinking, and Acceptance of Paranormal and Pseudoscientific Claims. Learning and Individual Differences, 36, 9-18. https://doi.org/10.1016/j.lindif.2014.07.009

Brown, L. T. (1983). Some More Misconceptions about Psychology among Introductory Psychology Students. Teaching of Psychology, 10, 207-210.

https://doi.org/10.1207/s15328023top1004_4

De Bruyckere, P., Kirschner, P., \& Hulshof, C. (2015). Urban Myths about Learning and Education. London: Elsevier. https://doi.org/10.1016/B978-0-12-801537-7.00003-2

Furnham, A. (1992). Prospective Psychology Students' Knowledge of Psychology. Psychological Reports, 70, 375-382. https://doi.org/10.2466/pr0.1992.70.2.375

Furnham, A. (1993). A Comparison between Psychology and Non-Psychology Students' Misperceptions of the Subject. Journal of Social Behavior and Personality, 8, 311-322.

Furnham, A. (2018). Myths and Misconceptions in Developmental and Neuro-Psychology. Psychology, 9, 249-259. https://doi.org/10.4236/psych.2018.92016 
Furnham, A., \& Hughes, D. (2014). Myths and Misconceptions in Popular Psychology: Comparing Psychology Students and the General Public. Teaching of Psychology, 41, 256-261. https://doi.org/10.1177/0098628314537984

Gardner, R. M., \& Dalsing, S. (1986). Misconceptions about Psychology among College Students. Teaching of Psychology, 13, 32-34.

https://doi.org/10.1207/s15328023top1301_9

Gardner, R. M., \& Brown, D. L. (2013). A Test of Contemporary Misconceptions in Psychology. Learning and Individual Differences, 24, 211-215. https://doi.org/10.1016/j.lindif.2012.12.008

Griggs, R. A., \& Ransdell, S. E. (1987). Misconceptions Tests or Misconceived Tests? Teaching of Psychology, 14, 210-214. https://doi.org/10.1207/s15328023top1404_4

Gaze, C. (2014). Popular Psychological Myths: A Comparison of Students' Beliefs across the Psychology Major. Journal of the Scholarship of Teaching and Learning, 14, 46-60. https://doi.org/10.14434/josotl.v14i2.3931

Hughes, S., Lyddy, P., \& Lambe, S. (2013). Misconceptions about Psychological Science: A Review. Psychology, Learning and Teaching, 12, 20-31. https://doi.org/10.2304/plat.2013.12.1.20

Hughes, S., Lyddy, P., \& Kaplan, R. (2015). Highly Prevalent But Not Always Persistent: Undergraduate and Graduate Student's Misconceptions about Psychology. Teaching of Psychology, 42, 34-42. https://doi.org/10.1177/0098628314562677

Hupp, S., \& Jewell, J. (2015). Great Myths of Child Development. New York: Wiley-Blackwell.

Jarrett, C. (2014). Great Myths of the Brain. New York: Wiley-Blackwell.

Jewell, J., Axelrod, M., Prinstein, M., \& Hupp, S. (2019). Great Myths of Adolescence. New York: Wiley-Blackwell.

Johnson, M. (2016). Great Myths of Intimate Relationships. New York: Wiley-Blackwell. https://doi.org/10.1002/9781118817469

Kowalski, P., \& Taylor, A. (2009). The Effect of Refuting Misconceptions in the Introductory Psychology Class. Teaching of Psychology, 36, 153-159. https://doi.org/10.1080/00986280902959986

LaCaille, R. (2015). Two Birds with One Myth-Debunking Campaign. Teaching of Psychology, 42, 323-329. https://doi.org/10.1177/0098628315603066

Lamal, P. A. (1979). College Students' Common Beliefs about Psychology. Teaching of Psychology, 6, 155-158. https://doi.org/10.1207/s15328023top0603_8

Lilienfeld, S., Lynn, S., Ruscio, J., \& Beyerstein, B. (2010). 50 Great: Popular Myths of Popular Psychology. Oxford: Wiley-Blackwell. https://doi.org/10.1038/scientificamericanmind0310-42

McKeachie, W. (1960). Changes in Scores on the Northwestern Misconceptions Test in Six Elementary Psychology Courses. Journal of Educational Psychology, 51, 240-244. https://doi.org/10.1037/h0048569

Nixon, H. (1925). Popular Answers to Some Psychological Questions. American Journal of Psychology, 27, 91-98. https://doi.org/10.2307/1414166

Standing, L., \& Huber, H. (2003). Do Psychology Courses Reduce Belief in Psychological Myths? Social Behavior and Personality, 31, 585-592.

https://doi.org/10.2224/sbp.2003.31.6.585

Swami, V., Thorn, L., Husbands, D., Tran, U. S., Nader, I. W., von Nordheim, L., Pietschnig, J., Stieger, S., \& Voracek, M. (2015). Are the Scope and Nature of Psychology Properly Understood? An Examination of Belief in Myths of Popular Psychology 
among University Students. In A. Columbus (Ed.), Advances in Psychology Research (Vol. 101, pp. 9-32). Hauppauge, NY: Nova Science Publishers. https://doi.org/10.2139/ssrn.2523661

Taylor, A., \& Kowalski, P. (2004). Naive Psychological Science: The Prevalence, Strength and Sources of Misconceptions, Psychological Record, 54, 15-25. https://doi.org/10.1007/BF03395459

Tupper, V., \& Williams, R. (1986). Unsubstantiated Beliefs among Beginning Psychology Students: 1925, 1952, 1983. Psychological Reports, 58, 383-388. https://doi.org/10.2466/pr0.1986.58.2.383

Vaughan, E. D. (1977). Misconceptions about Psychology among Introductory Psychology Students. Teaching of Psychology, 4, 138-141.

https://doi.org/10.1207/s15328023top0403_9 